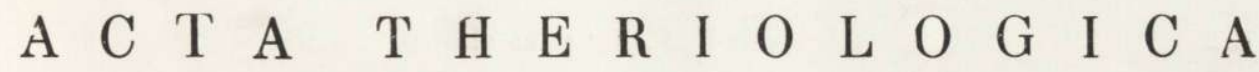 \\ VOL. XVI, 11: $161-177$. \\ BIAEOWIEŻA \\ August, 1971
}

Barry F. FA UST, Michael H. SMITH \& W. Bradley WRAY

\section{Distances Moved by Small Mammals as an Apparent Function of Grid Size*}

[With 5 Tables \& 4 Figs.]

Live traps were used on a $26 \times 26$ grid $(14.1 \mathrm{ha})$ to determine the movement patterns of three species of small mammals in a lowland mesic-hardwood forest. Blarina brevicauda moved an average of $94.7 \mathrm{~m}$ between succesive captures, Ochrotomys nuttalli $72.8 \mathrm{~m}$ and Peromyscus gossypinus $54.9 \mathrm{~m}$. These data are not consistent with Calhoun's theory of social dominance. Linear relationships are given for predicting home range size as calculated by several different methods from average distance between captures. A new way of depicting the distribution of distances between captures is given. Movements on the middle $16 \times 16$ grid compared to those on the $26 \times 26$ grid were $19.4 \%$ shorter for $O$. nuttalli and $25.1 \%$ shorter for P. gossypinus. Longer movements are extending the area of effect around a census grid or line farther than might be expected from data collected on smaller study plots. Thus, an upward bias is introduced into most density estimates.

\section{INTRODUCTION}

The general problem of routinely obtaining reliable density estimates for small mammal populations has not yet been solved. These estimates are important in such areas as public health, energy flow and mineral cycling in communities, and population ecology. Our failure to find a workable solution will and has impeded our progress in these areas.

At this stage of the research two important questions need to be answered. How long does it take to catch a substantial proportion of the small mammals in a defined area? Delayed inputs of certain species can result in inaccurate estimates of their population size if the sampling interval is short. Secondly, what are the normal movement patterns of the mammals during a time interval equal to that of the sampling period?

* This study was carried out under contract AT(38-1)-310 between the Atomic Energy Commission and the University of Georgia. 
Answers to these questions will aid in an independent evaluation of the estimates of the width of the border zone around the study plot from which animals are moving onto the plot and, thus, are included in the sample.

Two primary methods, mark-release and removal trapping, are used to census small mammal populations. In the latter, certain species are removed later in the sampling period than other species (Calhoun, 1963; Gentry, Golley \& Smith, 1968). Calhoun hypotheses that this is due to the rapid removal of the dominant species characterized by large home ranges and the subsequent enlargement of the home ranges of the subordinate or more slowly removed species in the absence of the dominant species. A species with a low density but high mobility might also have a low apparent capture rate and thus appear to be a subordinate species. The reasons for the delay could indicate the nature of certain biases in the calculation of our density estimates.

Thus our first objective in this study was to determine home ranges for three species of small mammals that occur together in the lowland mesic-hardwood forest of South Carolina. Using Calhoun's terminology, the cotton mouse, Peromyscus gossypinus (Le Conte, 1853) is the dominant species and both the short-tailed shrew, Blarina brevicauda (S a y, 1823), and golden mouse, Ochrotomys nuttalli ( $\mathrm{H}$ a r l a n, 1823) are subordinate species (Gentry, Smith \& Chelton, 1971). According to this hypothesis, home range size should be larger for P. gossypinus than for B. brevicauda or O. nuttalli.

Our second objective was to determine the rate at which the three species were captured using live trapping and mark-release techniques rather than snap trapping and removal of animals as in our previous studies (Ge ntry et al., 1968). If Calhoun's hypothesis is correct, the use of the former techniques should require longer time intervals for accurate density estimates, because the continued presence of the dominant animals should decrease the rate at which the subordinates are captured.

If longer time intervals are required to estimate population size, then the potential importance of long movement around the edge of the grid is greatly increased. With small study plots we cannot measure the longer movements of some mammals (e.g., $\mathrm{Smith}$, 1968). It has been proposed to use a $16 \times 16$ grid of 5.1 ha to determine small mammal densities as part of the International Biological Program (Grodziński, Pucek \& Ryszkowski, 1966). Small mammals in the forest habi at can and do move completely across areas larger than that occupied by this grid (unpublished results). Thus, our third objective was to 
document the extent of these longer movements so that they could be taken into account in density calculations.

\section{METHODS}

Home range data were collected for $P$. gossypinus, $O$ nuttalli and $B$. brevicauda. The study area was located in a lowland mesic-hardwood forest (as described by Ge ntry et al., 1968) on the Atomic Energy Commission's Savannah River Plant in South Carolina. Trapping was conducted for 63 consecutive days (June 17, $1969-$ August 18,1969 ) on a 14.1 ha grid with 26 lines and 26 rows (676 trap stations) with $15 \mathrm{~m}$ intervals between stations. Air temperature ranged from 17.0 to $35.2 \mathrm{C}$ ), and average daily rainfall was $0.15 \mathrm{~cm}$.

Equal numbers of Sherman and galvanized drop-door live traps were used one per station. Traps were placed at $50 \%$ of the trap stations selected daily at random. Traps were checked, moved to new locations if necessary, and set each morning. Movement of traps lessened the probability of capture of cartain animals and decreased trap interference with the normal activities of the animals.

Freeze-dried crickets mixed with peanut butter were used as bait and placed on $1.3 \mathrm{~cm}$ sheet metal screws driven into the back door of each trap. After July 13th, damp sponges, about $2 \mathrm{~cm}^{3}$, were placed in the back of each trap to avoid dessication of the animals (esp. Blarina). Ant powder was periodically sprinkled around certain traps to prevent captured animals from being stung to death. Species, sex, reproductive condition, and trap location were recorded for each animal. Each individual was marked by toe clipping and released at the site of capture.

The linear relationship between home range size $(Y)$ as measured in different ways and average distance between captures $(X)$ was determined by the method of least squares (Steel \& Torrie, 1960). Home range size was calculated by the circular method (Calhoun \& Casby, 1958), minimum area method ( $\mathrm{M} \mathrm{o} h \mathrm{hr}$, 1947), exclusive and inclusive boundary strip methods (Stickel, 1954), and the adjusted range length ( $A R L)$ method (S t i c k el, 1954). In the latter method, $A R L$ was used as the diameter of the home range in making area calculations. Sample size for the circular method was only eight $P$. gossypinus and six $O$. nuttalli because of the restriction that individuals had to be captured six or more times.

\section{RESULTS}

A total of 137 animals were caught during the 63 day trapping period. Of 26 O. nuttalli, 14 were recaptured one or more times. Thirty of 44 $P$. gossypinus and only 5 of $67 \mathrm{~B}$. brevicauda were recaptured. The low recapture rate for $B$. brevicauda was partially due to the death of 44 shrews in the traps. More male $(\mathrm{N}=20) O$. nuttalli were captured than females $\left(\mathrm{N}=6 ; \chi^{2}=7.54\right)$ but the sex ratio was approximately $1: 1$ for P. gossypinus $\left(25 \sigma^{7}, 19\right.$; $\left.; \chi^{2}=.82\right)$. Sex determination was doubtful for certain immature $B$. brevicauda, so the ratio was not calculated. The number of captures for each species in the two trap types did not differ 
Table 1

Observed and expected number of captures of three species of small mammals in two trap types.

\begin{tabular}{|c|c|c|c|c|}
\hline Species & $\begin{array}{l}\text { Trap } \\
\text { Type }\end{array}$ & $\begin{array}{l}\text { Number of } \\
\text { Captures } \\
\text { Observed }\end{array}$ & $\begin{array}{l}\text { Number of } \\
\text { Captures } \\
\text { Expected }\end{array}$ & $\chi^{2}$ \\
\hline $\begin{array}{l}\text { Peromyscus gossypinus } \\
\text { Total } \\
\text { Ochrotomys nuttalli } \\
\text { Total } \\
\text { Blarina brevicauda } \\
\text { Total }\end{array}$ & $\begin{array}{l}\text { Sherman } \\
\text { Galvanized } \\
\text { Drop-door } \\
\text { Sherman } \\
\text { Galvanized } \\
\text { Drop-door } \\
\text { Sherman } \\
\text { Galvanized } \\
\text { Drop-door }\end{array}$ & $\begin{array}{l}84 \\
63 \\
51 \\
39 \\
19 \\
13\end{array}$ & $\begin{array}{l}73.5 \\
73.5 \\
45 \\
45 \\
16 \\
16\end{array}$ & $\begin{array}{c}1.50 \\
1.50 \\
3.00^{*} \\
.80 \\
.80 \\
1.60^{*} \\
.56 \\
.56 \\
1.12^{*}\end{array}$ \\
\hline
\end{tabular}

* not significant at .05 level.

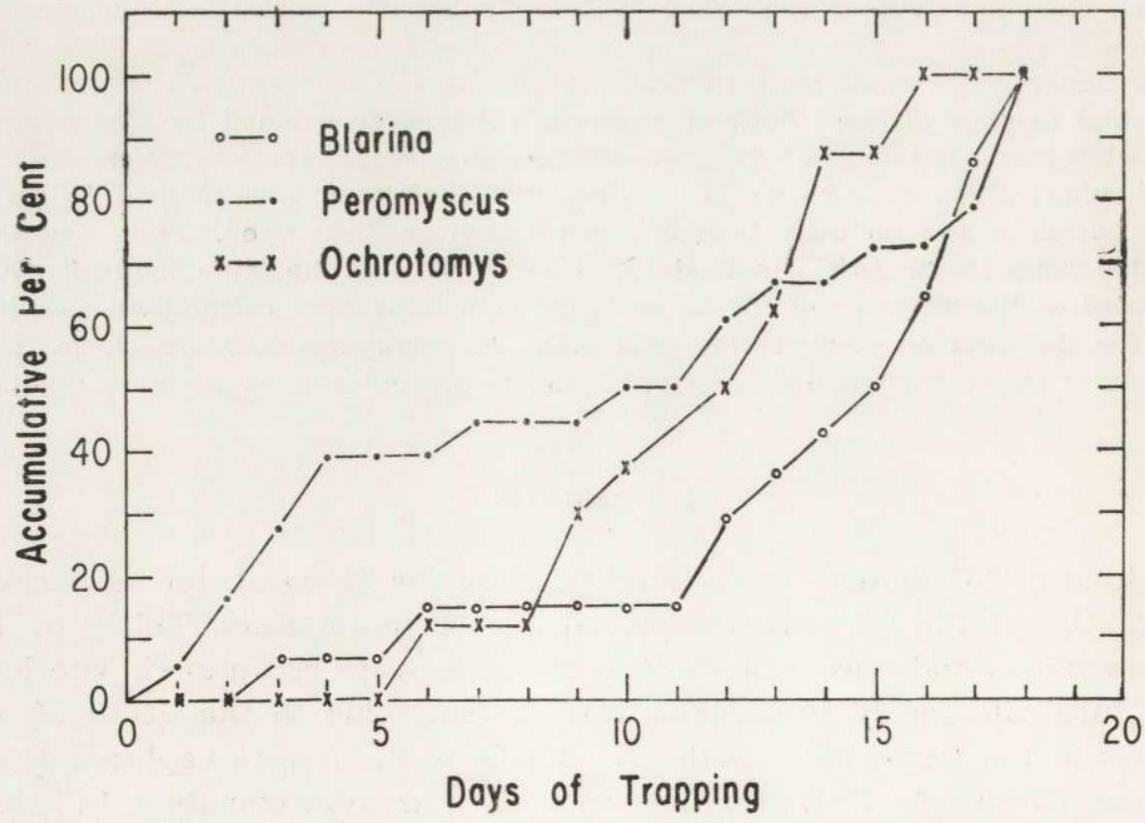

Fig. 1. Rates at which new animals of each species were captured during the first 18 trapping days. Only the first capture for each animal is used in the accumulation. Total number of animals in each species at 18 days was set at $100 \%$. 
significantly from a $1: 1$ ratio (Table 1 ). All of the animals recaptured were adults and none of the females appeared pregnant during the study.

\section{Rate of Removal}

Taking the total number of new animals captured during the first 18 days as $100 \%$, the accumulative percentages of individuals caught on successive days were calculated for each species (Fig. 1). By the fifth day of trapping $39 \%$ of the P. gossypinus, $7 \%$ of the B. grevicauda, and $0 \%$ of the $O$. nuttalli had been captured. By the tenth day $50 \%$ of the P. gossypinus, $37 \%$ of the $O$. nuttalli and $15 \%$ of the B. brevicauda

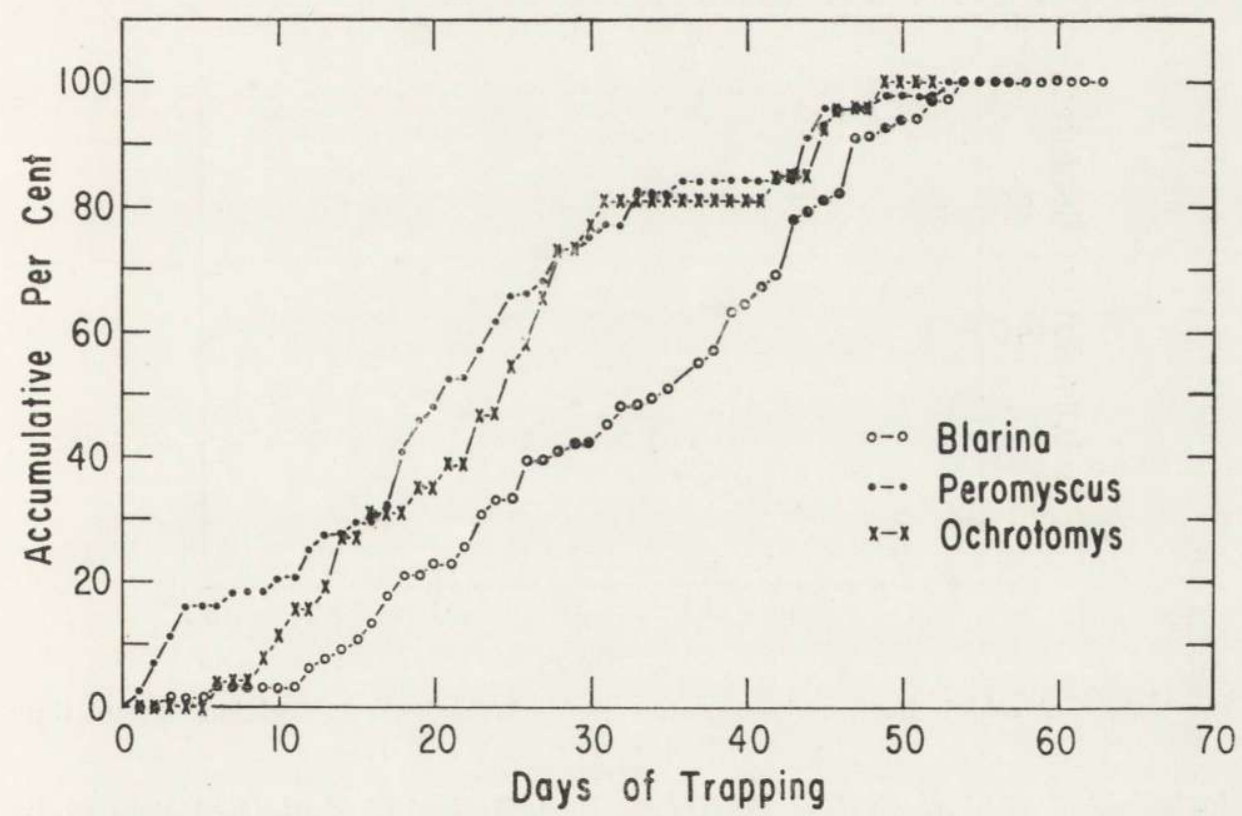

Fig. 2. Rates at which new animals of each species were captured during the first 63 trapping days. Only the first capture for each animal is used in the accumulation. Total number of animals in each species at 63 days was set at $100 \%$.

had been trapped. The percentage of $O$. nuttalli became greater than that of $P$. gossypinus after the 13th day. Similar trends in capture rates were found by Gentry et al. (1968) in a removal trapping study in the same type of habitat. Sixty-day capture rates for the three species also showed similar trends (Fig. 2). Although there were more B. brevicauda captured, their capture rate remained below those of the other two species. After the 23rd day the accumulative percentages of P. gossypinus and $O$. nuttalli were essentially the same. Between days 16 and 33 , $50 \%$ of the $P$. gossypinus were captured for the first time. Fifty percent 
of the $O$. nuttalli were captured between days 18 and 31 . Blarina brevicauda was caught at a more rapid rate between days 38 and 50 than between days 11 and 37 .

Changes in the rate of capture for all species combined expressed as number per day rather than percent per day can be seen in Fig. 3. The relatively constant rate of capture for the first 6 days was due to the rate for $P$. gossypinus. The rate of capture declined between days 7 and 11 because of a drop in the rate for $P$. gossypinus without a compensating increase in the rate for $O$. nuttalli and B. brevicauda. Blarina started being captured at a fairly constant rate from day 12 on; this accounted for the increased rate for all species between days 12 and 22 (Fig. 3).

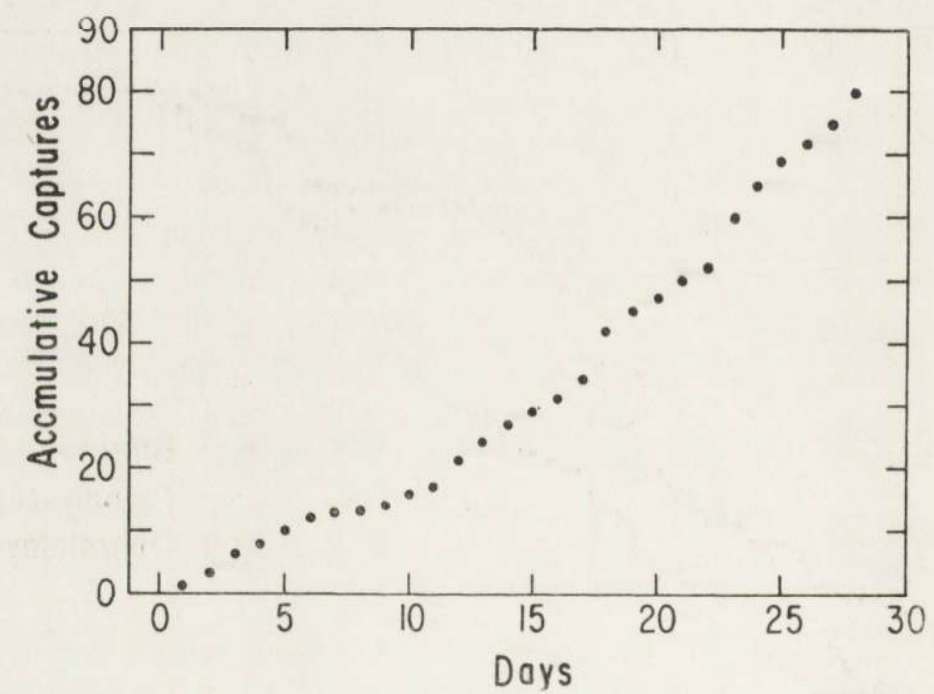

Fig. 3. Rate at which the number captures of all species accumulated versus time up to 28 days.

The capture rate for $O$. nuttalli and B. brevicauda remained relatively constant for days 12 through 28 , but $P$. gossypinus showed an increased rate between days 23 and 28 compared to that for days 12 through 22 . Since the supposed dominant species was not removed from the study area and the capture rates in this mark-release study and those in the removal trapping study showed similar trends, these results do not appear to support C al hou n's hypothesis (1963).

\section{Movement Patterns}

The average distance between captures $(A D B C)$ did not vary as a function of the number of recaptures for the three species (Table 2). The coefficient of variation for the $A D B C$ ranged from 71 to $146 \%$; however, 
$A D B C$ did not follow a normal distribution for any species. A square root transformation of the $A D B C$ resulted in an almost perfect normal distribution for each species - sex category. According to Sn ed e c or \& Cochran (p. 51, 1967), the test for normality expressing $A D B C$ as a standard measure should result in a mean of 0 and variance of 1 if the distribution is normal. The results were as follows: $\bar{X}=.000$ and $S^{2}=.999$ for $B$. brevicauda male and female combined, $P$. gossypinus males and females treated separately, and $O$. nuttalli females; $\bar{X}=.0087$ and $S^{2}=.987$ for $O$. nuttalli males.

\section{Table 2}

Average distances between captures as a function of accumulated number of capture for three species. The $16 \times 16$ in the middle of the $26 \times 26$ grid is treated separately. The mean $(X)$, standard deviation $\left(S_{x}\right)$, standard error $\left(S_{x}\right)$, coefficient of variation (C V), and home range from minimum area method (calculated in ha from $\bar{X}$ by $\bar{Y}=-0.254+0.0128 \bar{X}$ ) are given.

\begin{tabular}{|c|c|c|c|c|c|c|c|c|c|}
\hline Species & $\begin{array}{l}\text { Size } \\
\text { of } \\
\text { Grid }\end{array}$ & Sex & $\begin{array}{c}\text { Number } \\
\text { of } \\
\text { Recaptures }\end{array}$ & $\underset{\text { Size }}{\text { Sample }}$ & $\bar{x}$ & $\mathrm{~S}_{x}$ & $\mathrm{~S}_{x}^{-}$ & $\mathrm{CV}$ & $\begin{array}{l}\text { Home } \\
\text { Range }\end{array}$ \\
\hline \multirow{6}{*}{ O. nuttalli } & \multirow{6}{*}{$26 \times 26$} & \multirow{6}{*}{ Both } & 1 & 14 & 70.1 & 70.25 & 18.78 & 100.0 & .643 \\
\hline & & & $1-2$ & 26 & 56.2 & 60.14 & 11.81 & 107.0 & .465 \\
\hline & & & $1-3$ & 35 & 57.9 & 56.83 & 9.61 & 98.0 & .487 \\
\hline & & & $1-4$ & 42 & 65.0 & 58.77 & 9.06 & 90.0 & .578 \\
\hline & & & $1-5$ & 49 & 72.4 & 60.32 & 8.62 & 83.3 & .673 \\
\hline & & & 1 or more & 69 & 72.1 & 63.33 & 7.62 & 87.0 & .669 \\
\hline O. nuttalli & $26 \times 26$ & M & 1 or more & 58 & 77.6 & 66.24 & 8.78 & 85.0 & .739 \\
\hline O. nuttalli & $26 \times 26$ & F & 1 or more & 11 & 37.6 & 32.79 & 10.37 & 87.1 & .228 \\
\hline \multirow[t]{4}{*}{ O. nuttalli } & $16 \times 16$ & Both & 1 or more & 16 & 59.0 & 41.91 & 10.47 & 71.0 & .501 \\
\hline & & & & 30 & 61.6 & 90.36 & 16.51 & 146.0 & .534 \\
\hline & & & $1-2$ & 52 & 60.2 & 80.18 & 11.21 & 133.0 & .521 \\
\hline & & & $1-3$ & 72 & 54.2 & 69.41 & 8.18 & 128.0 & .439 \\
\hline \multirow[t]{3}{*}{ P. gossypinus } & $26 \times 26$ & Both & $1-4$ & 89 & 53.1 & 67.00 & 7.10 & 126.0 & .426 \\
\hline & & & $1-5$ & 101 & 56.3 & 72.18 & 7.18 & 128.0 & .466 \\
\hline & & & 1 or more & 114 & 53.6 & 66.85 & 6.07 & 124.0 & .432 \\
\hline P. gossypinus & $26 \times 26$ & M & 1 or more & 78 & 54.8 & 73.17 & 8.45 & 135.6 & .447 \\
\hline P. gossypinus & $26 \times 26$ & F & 1 or more & 36 & 48.6 & 49.29 & 7.79 & 101.4 & .368 \\
\hline \multirow[t]{2}{*}{ P. gossypinus } & $16 \times 16$ & Both & 1 or more & 12 & 41.1 & 33.20 & 9.59 & 80.0 & .272 \\
\hline & & & & 5 & 62.0 & 67.28 & 30.17 & 108.0 & .540 \\
\hline B. brevicauda & $26 \times 26$ & Both & 1 or more & 7 & 94.7 & 81.41 & 30.83 & 85.0 & .959 \\
\hline
\end{tabular}

Another way of examining the data is as follows: Each distance between successive captures $(D B C)$ in a given category was assigned a relative frequeny of $1 / N$, where $N$ is the number of recaptures in the category (see $\mathrm{S} \mathrm{mith}$, in press for a similar treatment). They were then rank ordered with largest $D B C$ first and the smallest last. $D B C s$ of 0 were excluded from the calculations because the theoretical frequency of occurrence for this distance should include data for consecutive captures of animals in the same trap and for animals not recaptu- 


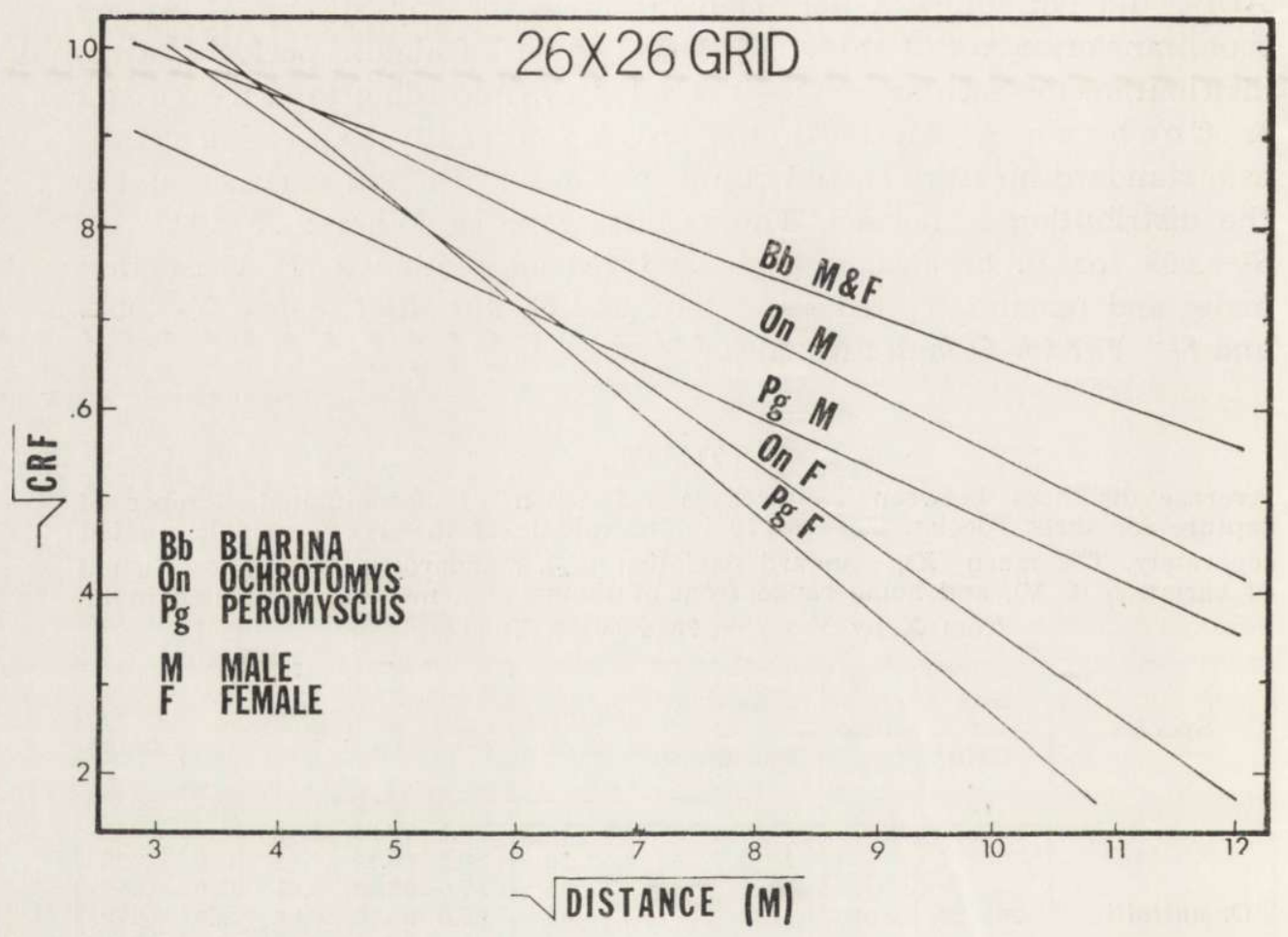

Fig. 4. Linear relationships between the square root of the cumulative relative frequency $(C R F)$ of the animals in each species - sex category and the square root of the mean distance moved between successive captures by individual animals The frequency of the animals was accumulated starting at the greatest distance and proceeding to the shortest distance.

\section{Table 3}

The relationship between the square root of the cumulative relative frequency $(Y)$ and square root of the distance between captures $(X)$ for each species-sex category. Any two slopes not underlined by the same line are different at the .05 level as tested by a $t$ test.

\begin{tabular}{|lcccc|}
$\begin{array}{c}\text { P. gossypinus } \\
\text { Females }\end{array}$ & $\begin{array}{c}\text { O. nuttalli } \\
\text { Females }\end{array}$ & $\begin{array}{c}\text { O. nuttalli } \\
\text { Males }\end{array}$ & $\begin{array}{c}\text { P. gossypinus } \\
\text { Males }\end{array}$ & $\begin{array}{c}\text { B. brevicauda } \\
\text { Males and } \\
\text { Females }\end{array}$ \\
\hline $\mathrm{Y}=1.34-0.112 \mathrm{X}$ & $\mathrm{Y}=1.30-0.095 \mathrm{X}$ & $\mathrm{Y}=1.11-0.067 \mathrm{X}$ & $\mathrm{Y}=1.11-0.063 \mathrm{X}$ & $\mathrm{Y}=1.13-0.046 \mathrm{X}$ \\
\hline & &
\end{tabular}

red (see Tanto n, 1969 for a similar situation). The latter category can only be estimated. Relative frequencies of the $D B C$ are added in z cumulative fashion along the rank order from 1 to $N$; this results in 
values $1 / N, 2 / N, 3 / N \ldots$ and $N / N$ or 1 . The relationship between the square root of the cumulative relative frequency $(Y)$ and the square root of the $D B C(X)$ was linear for each species-sex category (Fig. 4 and Table 3). Differences between slopes for the species-sex categories are summarized in Table 3.

$A D B C$ of animals recaptured anywhere on the $26 \times 26$ grid were compared with those for animals recaptured on the $16 \times 16$ grid in the middle of the larger plot (Table 2). Only $23.2 \%$ of the O. nuttalli and $10.5 \%$ of the $P$. gossypinus recaptures occured in the middle $16 \times 16$ grid. $A D B C$ on the middle $16 \times 16$ compared to those on the $26 \times 26$ grid. were $19.4 \%$ shorter for $O$. nuttalli and $25.1 \%$ shorter for P. gossypinus. There were not enough recaptures for B. brevicauda in the middle $16 \times 16$ grid to make this comparison.

Home range $(Y)$ as measured directly by various methods for animals caught four or more times was regressed against their $A D B C$ (X; Table 2). The correlation coefficients $(r)$ for these significant $(P<.05)$ linear relationships ranged from .60 to .84 . Estimated home range size was calculated from the $A D B C$ for all animals in a given category (e. g., O. nuttalli, $26 \times 26$ grid and $\sigma^{*}$, Table 4). Estimated values were higher six times and lower four times than those measured directly for each method. The difference between the estimated home range size and that measured directly divided by the latter for each method averaged $34.9+11.0 \%(S)$ and ranged from $1.6 \%$ for the minimum area method for $O$. nuttalli to $87.8 \%$ for the same method for P. gossypinus. The coefficient of determination $\left(r^{2}\right)$ or that proportion of the total sums of squares attributable to the regression averaged $58.8 \%$ for all methods of calculating home range.

\section{DISCUSSION}

Problems associated with the development and application of a relatively static home range concept for small mammals (B u r t, 1940, 1943) have been considerable. One of the reasons for this has been the inability or unwillingness of investigators to accept the extent to which small mammals move. The relatively small size of most study areas is also a bias that is inherent in practically all investigations. Long range movements are not likely to be recorded because the animals move off the study plot. Animals not resident on the plot might be assigned to a category of »transient « or »ephemeral " (e.g., Shadowe n, 1963) if they occur on the study area infrequently and in an erratic spatial pattern. 


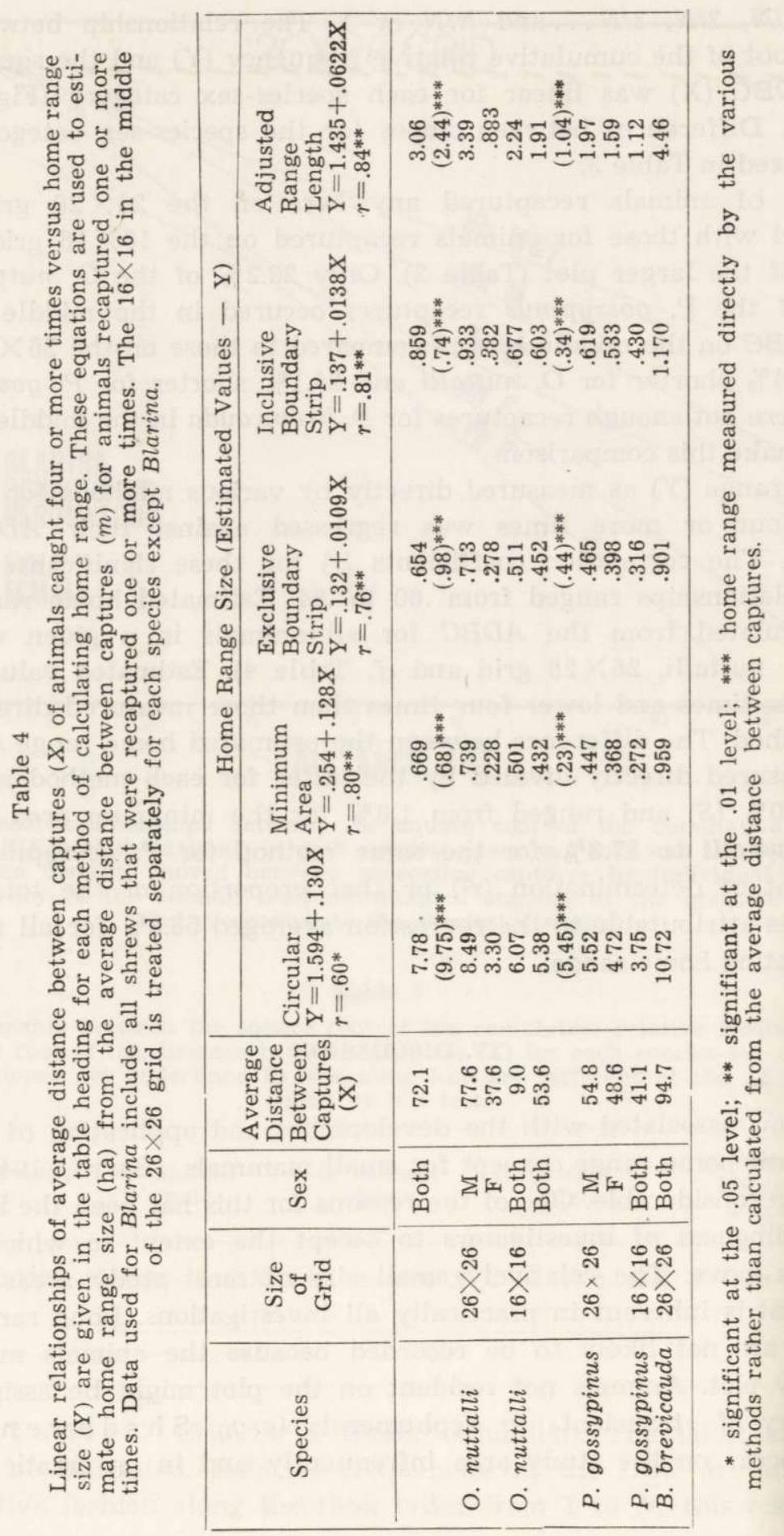


Both species for which the data were appropriate moved farther on the $26 \times 26$ than on the $16 \times 16$ grid (Table 2). A few mice of both species moved over $350 \mathrm{~m}$ and other probably moved farther than the width of the grid $(375 \mathrm{~m})$. Mice were frequently captured in traps separated from each other by many trap stations but were not caught at intervening stations. Their probability of capture must be close to 0 when they are moving between distant points. This low probability of capture and the small size of most study plots helps explain how home range was erroneously concluded to be relatively static.

The coefficient of variation for movement data was around $100 \%$ (Table 2) which is approximately an order of magnitude higher than that for morphometric data (Simpson, Roe \& Lewontin, 1960). The large variances and relatively large means necessitate a large study plot for accurate estimation of these statistics. In addition, including

Table 5

The median, average and maximum distance between captures in meters for various species-sex categories. The median and maximum were calculated from the relationship between the square roots of cumulative relative frequency and distance between captures (Fig. 4). Average distances were calculated directly (Table 2).

\begin{tabular}{|l|c|c|c|c|c|}
\hline & $\begin{array}{c}\text { P. gossypinus } \\
\text { Females }\end{array}$ & $\begin{array}{c}\text { O. nuttalli } \\
\text { Females }\end{array}$ & $\begin{array}{c}\text { O. nuttalli } \\
\text { Males }\end{array}$ & $\begin{array}{c}\text { P. gossypinus } \\
\text { Males }\end{array}$ & $\begin{array}{c}\text { B. brevicauda } \\
\text { Males \& } \\
\text { Females }\end{array}$ \\
\hline Median & 32.0 & 39.0 & 34.4 & 38.9 & 73.7 \\
Average & 48.6 & 37.6 & 77.6 & 54.8 & 94.7 \\
Maximum & 143.0 & 187.1 & 274.6 & 310.5 & 603.7 \\
\hline
\end{tabular}

data from animals living on the edge of a small grid in calculations of movement or density introduces a relatively large bias even if they have been caught several times.

Calculation of density represents one of the primary goals in many IBP related studies (e. g., Grodziński et al., 1966). It is usually assumed that the sampling area is equal to the area of the grid plus a small border zone frequently equal in width to one half the distance between trap stations (A ula k, 1967). The actual border zone must be much wider than $7.5 \mathrm{~m}$ (Chełkowska \& Ryszkowski 1967); it is greater than the median distance between captures but less than the maximum distance between captures ( $\mathrm{Che} \mathrm{kkowska} \& \mathrm{Ryszkow}-$ ski, 1967; Ada mczyk \& Ryszkowski, 1968; Table 5). To calculate the exact width of the border zone requires extensive data on the frequency distribution of individual movement as a function of time. 
The capture rate in this study was extremely low, so it is not possible to do these calculations.

Several investigators have studied movement in $P$. gossypinus ( $\mathrm{P}$ o u rnelle, 1950; Pearson, 1953; McCarley, 1959; Griffo, 1961; Shadowen, 1963; Stephenson, Goodrum, \& Pac$\mathrm{k}$ a rd, 1963). Only two of these investigators (M c Carley, 1959; $\mathrm{Gr}$ if f o, 1961) reported average distance moved or home ranges greater than those in this study. There has been a small usually insignificant difference between the distances moved by males and females. However, males have consistently moved farther than females and the large variances and small sample sizes have made it impossible to show this difference to be significant in individual studies. A sign test (S t e e l \& Torrie, 1960) using the data in all of the studies can be used to show that in $P$. gossypinus males move farther than females $\left(\chi^{2}=5.14\right.$, $P<.05$ and $d f=1)$.

Golden mice moved $72.8 \pm 15.2 \mathrm{~m}( \pm 2$ S.E.) between captures as compared with $54.9 \pm 12.1 \mathrm{~m}$ for the cotton mouse and $94.7 \pm 61.6 \mathrm{~m}$ for the short tailed shrew. Males of $O$. nuttalli $(77.6 \pm 17.6 \mathrm{~m})$ moved significantly farther than females $(37.6 \pm 20.7 \mathrm{~m})$. Other investigators have not found a significant difference in the movement distances of males and females in this species (McCarley, 1958; Linzey, 1968). Home range values (Table 1) for $O$. nuttalli in our study are larger than any previously reported for the species (D unaway, 1955; M c Carley, 1958; Redman \& Sealander, 1958; Shadowen, 1963; Lin$\mathrm{ze} y, 1968)$. If only the data for the middle $16 \times 16$ are included, our values are still higher than those reported in the other studies. There are no obvious correlations between movement distances and environmental variables in the different studies.

The distribution of average distance between captures showed relatively more short tailed shrews moving farther than cotton mice and golden mice (Table 3). This might be expected since Blarina are more carnivorous than the other two species of mice (Calhoun, 1941; E a d i e, 1944; L in z e y, 1968). However, according to Calhoun's theory of interspecific social dominance, the dominant species should be captured at a more rapid rate and have larger home ranges than the subordinate species. $P$. gossypinus was initially captured at the highest rate followed by $O$. nuttalli and B. brevicauda (Fig. 3). Yet P. gossypinus did not have the largest home range (Tables 2 and 4). Since P. gossypinus is usually captured at a more rapid rate than the other two species Gentry, Smith, \& Chelton, 1971) and has an $A D B C$ no higher than that of the other species, Calhoun's theory in respect to interspecific interactions must be rejected and some other explanation found. Intraspe- 
cific interactions surely influence trapping results (e.g., G e n try, et al., 1968 for P. gossypinus; B r ow n, 1969).

Perhaps the simplest explanation is that $P$. gossypinus has a relatively stronger neophilic reaction ( $\mathrm{S}$ h e p p e, 1966) to traps than B. brevicauda and $O$. nuttalli. This reaction can be occassionally modified as evidenced by the rapid rate of capture of $B$. brevicauda on the first standard minimum grid run in South Carolina (Gentry, Golley \& Smith, 1968). However, it is likely that shrews in general show a marked avoidance of strange objects in a variety of habitats ( $\mathrm{Brown}, 1967$; Gentry, Smith \& Chelton, 1971). If the trap response of a species were determined by the neophilic and neophobic reactions, then the initial trap response might be quite different than subsequent responses. Although $O$. nuttalli was captured for the first time at a slower rate, over a 63 day period they were captured approximately the same number of times per individual as was P. gossypinus. Once Ochrotomys entered the trap sample, it was recaptured at a more rapid rate than was $P$. gossypinus. Since that supposed dominant species was not removed from the plot, $O$. nuttalli should have continued to be inhibited in its movements by the presence of $P$. gossypinus and should have had a recapture rate equal to the initial capture rate. This inconsistency along with the spatially dynamic nature of the small mammal community again leads us to reject Calhoun's theory.

Interspecific social interactions may influence trapping results, but 1t tes not keen possible to irdependently evaluate their effects because of other important behavioral characteristics, such as reaction to strange objects. Initial reactions do vary between species and the three major species in our investigation should be studied in this regard.

A detailed analysis of movement data usually results in the question of which method of home range calculation is best (e.g., Van V l e ck, 1969). Even if one method were better than the others, most methods give answers that are relative to the unknown true value, and the answers are linearly related to each other (Table 4). It should be possible to develop a matrix of predictive equations to relate different measures of home range or linear movements to each other. Preliminary analyses indicate that these equations seem to be independent of species and to have a high degree of predictability ( $\mathrm{S} \mathrm{mith}$, unpubl.).

Calhoun \& Casby's (1958) circular model of home range is dependent upon the normal bivariate distribution and may be an exception to the above generalizations. This method gives extremely large home ranges (Table 4), and these results have a lower correlation with $A D B C$ than those of any other method. It is also necessary in this method to subjectively reject more data than the amount used in the 
final analysis. If the absolute rigid requirements were met to test the circular model, none of our data would have been suitable. We feel that the pimary reason for this situation is that animals do not move in the way Calhoun \& Casby (1958) assume. When the grid is large enough, most animals exhibit long movements that would disqualify them for further analysis. The circular model of $\mathrm{Calh}$ oun \& $\mathrm{Cas}$ by (1958) is of no practical use in analyzing the majority of data obtained in studies of small mammal movements.

Studies on movement patterns usually involve long time intervals. This depends upon the necessity of capturing an animal at least several times before applying accepted methods of calculating home range. Simultaneous comparative studies are usually not attempted because of the amount of labor needed at one time. Since home range can be predicted from the $A D B C$ value for the first recapture as well as subsequent ones, there is no need to prolong the study on one plot if a large enough number of animals were recaptured the first time. Studies should be designed to evaluate the effects of various environmental factors (e. g., density and species composition) on movement patterns. A few days on each plot should be sufficient to establish the slope and intercept for the relationship between the cumulative relative frequency and distance between captures (Fig. 4). The implications of this type of data for the evolution of small mammal populations should be recognized.

Rodent populations seem to be genetically subdivided on a microgeographic scale (R a s m u s s e n, 1964; S m ith, 1966; P e tra s, 1967; Selander, 1970). Long range movements such as those given in Table 2 and by A d a m c z y k \& R y s zkowski (1968) are inconsistent with the concept of local subdivision unless most movement is unrelated to genetic exchange between established populations. The only species studied thus far for local subdivision are characteristic of early stages of primary or secondary succession; one of these species ( $P$. polionotus) has approximately the same distribution of movement distances as does P. gossypinus and O. nuttalli ( $\mathrm{Smith}, 1971)$. The movement patterns of these three species do not appear to be related to the stage of succession (old fields versus forest) nor to the geographic location of the study sites (A damczyk \& Ryszkow ski, 1968). In addition the amount of movement is probably not a function of the energy demands of individual mice (B o i z e, 1970).

Long movements may be a primary adaptation for founding new populations rather than for genetic exchange between existing populations. The relatively high occurrence of longer movements must be related to the high probability of founding a new population, since excessive movements increases exposure to predators and thus probable death 
on unfamilar terrain (M e t z g a r, 1967). Local extinction of populations must be common or else there would not be any place to found new populations. Further discussion in this area depends upon new data concerning population stability through time and actual genetic exchange and not just individual movement.

Acknowledgements: We thank Ronald Blessing, Paul Ramsey and Beyers Wray for their assistance with the field work and John Gentry, Whitfield Gibbons, Frank Golley, Donald Kaufman, and Linda Ramsey for critically reading parts of the manuscript.

\section{REFERENCES}

1. Adamczyk K. \& Ryszkowski L., 1968: Estimation of the density of a rodent population using stained bait. Acta theriol., 13: 295-311.

2. A u lak W., 1967: Estimation of small mammal density in three forest biotopes. Ekol. pol. A, 15: 755-778.

3. B oize B. J., 1970: Behaviour and home range size in the old-field mouse, Peromyscus polionotus. Unpubl. Masters Thesis, Univ. Geogria, 51 p.

4. Brown L. E., 1969: Field experiments on the movements of Apodemus sylvaticus L. using trapping and tracking techniques. Oecologia, 2: 198-222.

5. Brown L. N., 1967: Ecological distribution of six species of shrews and comparison of sampling methods in the central rocky mountains. J. Mamm., 48: $617-623$.

6. Burt W. H., 1940: Territorial behavior and populations of some small mammals in southern Michigan. Misc. Publ. Mus. Zool. Univ., 45: 1-58.

7. Burt W. H., 1943: Territoriality and home range concepts as applied to mammals. J. Mamm., 24: 346-352.

8. Calhoun J. B., 1941: Distribution and food habits of mammals in the vicinity of the Reelfoot Lake Biological Station. J. Tennessee Acad. Sci., 6: 177-185, $207-225$.

9. Calh ou n J. B., 1963: The social use of space, [In: »Physiological mammalogy«, Eds., Mayer W. \& Van Gelder R.], Academic Press: 1: 1-187. New York.

10. Calhoun J. B \& Casby J U, 1958: Calculation of home range and density of small mammals. Public Health Mono., 53: 1-24.

11. Chelkowska H. \& Ryszkowski L., 1967: Causes of higher abundance estimates of small rodents at the edges of sampling areas in forest ecosystems. Ekol. pol. A, 15: 737-746.

12. Davis D. E., 1953: Analysis of home range from recapture data. J. Mamm., 34: $352-358$.

13. Dunaway P. B., 1955: Late fall home ranges of three golden mice, Peromyscus nuttalli. J. Mamm., 36: 297-298.

14. Eadie W. R., 1944: The short-tailed shrew and field mouse populations. J. Mamm., 25: 359-364.

15. Gentry J. B., Golley F. B \& Smith M. H., 1968: An evaluation of the proposed International Biological Program census method for estimating small mammal populations. Acta theriol., 13: 313-327.

16. Gentry J. B., Smith M. H. \& Chelton J. G., 1971: An evaluation of the octagon census method for estimating small mammal populations. Acta theriol.. 16: $149-159$. 
17. Griffo J. V., Jr., 1961: A study of homing in the cotton mouse, Peromyscus gossypinus. Amer. Midl. Nat., 65: 257-289.

18. Grodziński W., Pucek Z. \& Ryszkowski L., 1966: Estimation of rodent numbers by means of prebaiting and intensive removal. Acta theriol., 11: $297-314$.

19. Linzey D. W., 1968: An ecological study of the golden mouse Ochrotomys nuttalli in the Great Smoky Mountains National Park. Amer. Midl. Nat., 79: $320-345$.

20. M c Carley W. H., 1958: Ecology, behavior and population dynamics of Peromyscus nuttalli in eastern Texas. Texas J. Sci., 10: 147-171.

21. M c Carley W. H., 1959: A study of the dynamics of a population of Peromyscus gossypinus and $P$. nuttalli subjected to $X$-irradiation. Amer. Midl. Nat., 61: $447-469$.

22. M etzgar L. H., 1967: An experimental comparison of screech owl predation on resident and transient white-footed mice (Peromyscus leucopus). J. Mamm., 48: $387-391$.

23. M o h r C. O., 1947: A table of equivalent populations of North American small mammals. Amer. Midl. Nat., 37: 223-249.

24. Pearson P. G., 1953: A field study of Peromyscus populations in Gulf Hammock, Florida. Ecology, 34: 199-207.

25. Petras M. L., 1967: Studies of natural populations of Mus. I. Biochemical polymorphisms and their bearing on breeding structure. Evolution, 21: 259-274.

26. Pournelle G. H., 1950: Mammals of a north Florida swamp. J. Mamm., 31: $310-319$.

27. Rasmussen D. I., 1964: Blood group polymorphism and inbreeding in natural populations of the deer mouse Peromyscus maniculatus. Evolution 18: 219-229.

28. Redman J. P. \& Sealander J. A., 1958: Home ranges of deer mice in southern Arkansas. J. Mamm., 39: 390-395.

29. Sela nder R. K., 1970: Behavior and genetic variation in natural populations. Am. Zool., 10: 53-66.

30. Shadowen H. E., 1963: A live trap study of small mammals in Louisiana. J. Mamm., 44: 103-108.

31. Sheppe W., 1966: Exploration by the deer mouse, Peromyscus leucopus. Amer. Midl. Nat., 76: 257-276.

32. Simpson G. G., Roe A. \& Lew ontin R. C., 1960: Quantitative zoology. Harcourt: $1-440$. New York.

33. Smith M. H., 1966: The evolutionary significance of certain behavioral, physiological, and morphological adaptations of the old-field mouse, Peromyscus polionotus. Unpubl. Ph. D. Diss., Univ. Florida, 186p.

34. S mith M. H., 1968: Dispersal of the old-field mouse, Peromyscus polionotus. Bull. Ga. Acad. Sci., 26: 46-51.

35. Smith M. H., 1971: Food as a limiting factor in the population ecology of Peromyscus polionotus (W a g n e r). Ann. Zool. Fenn. 8: 109-112.

36. Snedecor G. W. \& Cochran W. G., 1967: Statistical methods. Sixth ed. Iowa State Univ. Press: 1-593. Ames.

37. St e el R. \& Torrie J., 1960: Principles and procedures of statistics. McGraw-Hill Book Co.: 1-481. New York.

38. Stephenson G., Goodrum P. \& Pacerd R. 1963: Small rodents as consumers of pine seed in east Texas uplands. J. Forest., 61: 523-526. 
39. Stickel L. F., 1954: A comparison of certain methods of measuring ranges of small mammals. J. Mamm., 41: 433-441.

40. Tanton M. T., 1969: The estimation and biology of populations of the bank vole (Clethrionomys glareolus (Schr.)) and wood mouse (Apodemus sylvaticus (L.)). J. Anim. Ecol., 38: 511-530.

41. Van Vleck D. B., 1969: Standardization of Microtus home range calculation. J. Mamm., 50: 69-80.

Accepted, March 28, 1971

Savannah River Ecology Laboratory, SR00, Box A, and
(M. Smith only)

Department of Zoology and Institute of Ecology,

University of Georgia,

Athens, Georgia, USA, 30601.

Barry F. FAUST, Michael H. SMITH i W. Bradley WRAY

\section{ODLEGŁOSCI PRZEBYWANE PRZEZ DROBNE SSAKI JAKO FUNKCJA WIELKOSCI POWIERZCHNI}

\section{Streszczenie}

W celu zbadania przemieszczeń drobnych ssaków w nizinnym mezotroficznym lesie liściastym zastosowano pułapki żywołowne rozmieszczone w siatce o wielkości $15 \times 15 \mathrm{~m}$ na powierzchni 14,1 ha (26 linii po 26 pułapek w linii). Osobniki Blarina brevicauda (S a y, 1823) przemieszczały się przeciętnie o $94,7 \mathrm{~m}$ pomiędzy kolejnymi złowieniami, Ochrotomys nuttalli (Harlan, 1823) - o $72,8 \mathrm{~m}$ a Peromyscus gossypinus (Le Conte, 1853) - o $54,9 \mathrm{~m}$. Ten ostatni gatunek łowił się w najszybszym tempie a $B$. brevicauda w najwolniejszym. Odwrotna zależność pomiędzy tempem odławianina się a odległościami przemieszczeń jest zgodna $\mathrm{z}$ teorią Calhoun'a (1963) o dominancji socjalnej. Przedyskutowano inne, możliwe wyjaśnienia tej zależności. Podano liniowe zależności do określenia areału osobniczego wyliczonego przy pomocy kilku różnych metod na podstawie przeciętnej odległości pomiędzy złowieniami. Przemieszczenia w środkowej części powierzchni $(16 \times 16$ rzędów pułapek) były w porównaniu z całą działką $(26 \times 26)$ o $19,4 \%$ krótsze u O. nuttalli i o $25,1 \%$ krótsze u $P$. gossypinus. Większe przemieszczenia rozciągają obszar oddziaływania działki lub linii inwentaryzacji bardziej, niż można oczekiwać na podstawie danych zebranych na wewnętrznych częściach powierzchni odłownych. A zatem do większości oszacowań zagęszczenia wprowadza się zawyżające odchylenie. 